\title{
Qi Gong and Heart Rate Variability: A Systematic Review
}

\section{Carla Cristina Ramos ${ }^{1}$, Elias de França ${ }^{1}$, Thatiana Lacerda Nobre ${ }^{1}$, Jeferson Oliveira Santana ${ }^{1}$, Diana Madureira', Cesar Augustus Sousa Zocoler ${ }^{1}$, Bruno Rodrigues ${ }^{2}$, Ronaldo V. T. Santos ${ }^{3}$, Iris Calado Sanches ${ }^{1}$, Erico Caperuto ${ }^{*}$}

\author{
${ }^{1}$ Gepame-Human Movement Laboratory, São Judas Tadeu University, São Paulo, Brazil \\ ${ }^{2}$ Unicamp-Physical Education College, São Paulo, Brazil \\ ${ }^{3}$ Unifesp-Campus Santos, São Paulo, Brazil \\ Email: *ericocaperuto@gmail.com
}

How to cite this paper: Ramos, C.C., de França, E., Nobre, T.L., Santana, J.O., Madureira, D., Zocoler, C.A.S., Rodrigues, B., Santos, R.V.T., Sanches, I.C. and Caperuto, E. (2017) Qi Gong and Heart Rate Variability: A Systematic Review. Journal of Biosciences and Medicines, 5, 120-127. https://doi.org/10.4236/jbm.2017.53013

Received: October 15, 2016 Accepted: March 24, 2017

Published: March 27, 2017

Copyright $\odot 2017$ by authors and Scientific Research Publishing Inc. This work is licensed under the Creative Commons Attribution International License (CC BY 4.0).

http://creativecommons.org/licenses/by/4.0/

\begin{abstract}
Qì Gōng is a type of exercise that involves meditation and is used for health. With a background from the martial arts, it is known also as an auto healing exercise with three main elements according to Traditional Chinese Medicine (TCM): body focus (posture and movement), breathing and mind focus (meditative elements). Heart rate variability is a tool that allows us to measure the autonomic system velocity to detect and respond to unexpected stimuli. So our goal was to build a systematic review of Qi Gong and Heart rate variability. PUBMED, EBSCO and Science Direct data bases were searched. Key terms (MeSH) were Heart Rate Variability and Ch'i Kung OR Qi Gong with a 10year filter. Four independent reviewers analyzed all articles and excluded duplicated articles, articles in Chinese and articles with no adherence to the subject. The end result was 5 studies selected. Our results showed no significant improvements in HRV with the practice of Qì Gōng, probably because of data heterogeneity. We found 5 types of Qì Gōng, 3 different instruments and different time intervals to measure HRV and 2 different age groups in the studies. We can conclude that there is evidence that Qì Gōng can improve HRV but studies that would use the same parameters are needed to further confirm that.
\end{abstract}

\section{Keywords}

Qi Gong, Heart Rate Variability, Meditation Exercises, Exercise Physiology

\section{Introduction}

Ancient China knowledge is deeply present in its Medicine. Some of its pillars are adequate nutrition, phytotherapy, acupuncture, massage and regular physical 
exercise. One of these pillars is Qì Gōng.

Qì Gōng is a physical exercise that involves meditation and is widely used for health. With a background from the martial arts, it is known also as an auto healing exercise with three main elements according to Traditional Chinese $\mathrm{Me}$ dicine (TCM): body focus (posture and movement), breathing and mind focus (meditative elements).

Qì Gōng means "vital energy work", where Qì is everything that controls our body, our vital energy and Gōng is work, the work that might improve and cultivate this energy. It's understood as a traditional biofeedback therapy and the Qi activation can be reached by breathing control and the achievement of a special mental state [1]. Wang et al., (2014) divided Qi Gōng in some categories: static, dynamic, internal (nei $q \hat{i}$ ) and external (wei $q \hat{i}$ ) and states that it can be practiced in several ways, for example, standing or seated [2].

The autonomic nervous system is divided in 2 parts that act in a balanced way, the sympathetic nervous system and the parasympathetic nervous system. The balance of these systems results in homeostasis [3].

As Qì Gōng is an active meditative strategy, it helps to balance the autonomic nervous system and all the structures controlled by it. For example, theautonomic nervous system influences the cardiovascular system in two ways, tonic and reflexively and there are some elements that might interfere positively in this control such as Qì Gōng or negatively as daily stress, posture changes and involuntary breathing control [4].

Heart Rate Variability (HRV) assessment helps to understand how the cardiovascular system adapts to the changes caused by the environment, and to measure the autonomic system velocity to detect and respond to unexpected stimuli [5].

Autonomic control assessment by HRVin Qì Gōng practice has been made in some studies. But because of different variables considered, different age groups and different measuring techniques, there are several aspects of this phenomenon that need to be further investigated.

\section{Objective}

The objective of this study is to further understand the effects of Qi Gōng on autonomic control, especially on its sympathetic and parasympathetic system branches, through a systematic literature review.

\section{Methods}

We searched PUBMED, EBSCO and Science Direct.

In all databases we used the following key terms (MeSH): 1) "Heart Rate Variability"; 2) "Ch'i Kung” OR "Qi Gong” and 3) "Heart Rate Variability” plus "Ch'i Kung” OR “Qi Gong”, all searches were did with a 10 years filter (2006-2016).

Two independent reviewers read all articles titles and abstracts and as excluding criteria we used duplicated articles, articles that were only in Chinese (most common language on the topic), because we understand that Chinese is an im- 
portant, but local language or articles that didn't have any relationship of HRV and Qi gong although the keywords were in the title or abstract. The end result was 7 studies that were initially selected.

After a more detailed investigation, 2 more articles were excluded. The first one mentioned HRV, but didn't have any results about it and the second one used only HR and not HRV as an assessment tool. Figure 1 below shows the articles search and selection fluxogram.

\section{Results}

Of the 5 remaining studies, we found a total number of 334 participants. From the 5 studies, one had only one experimental group of Qì Gōng while the others had two groups, one is experimental and other control group. The 5 studies can be seen in Table 1 .

\section{Discussion}

All studies used Internal Qì Gōng. Amongits many types we found the following: Qì Gōng: BāDuànJinn (8 Pieces of Brocade), Dharma Drum (Dharma drum),

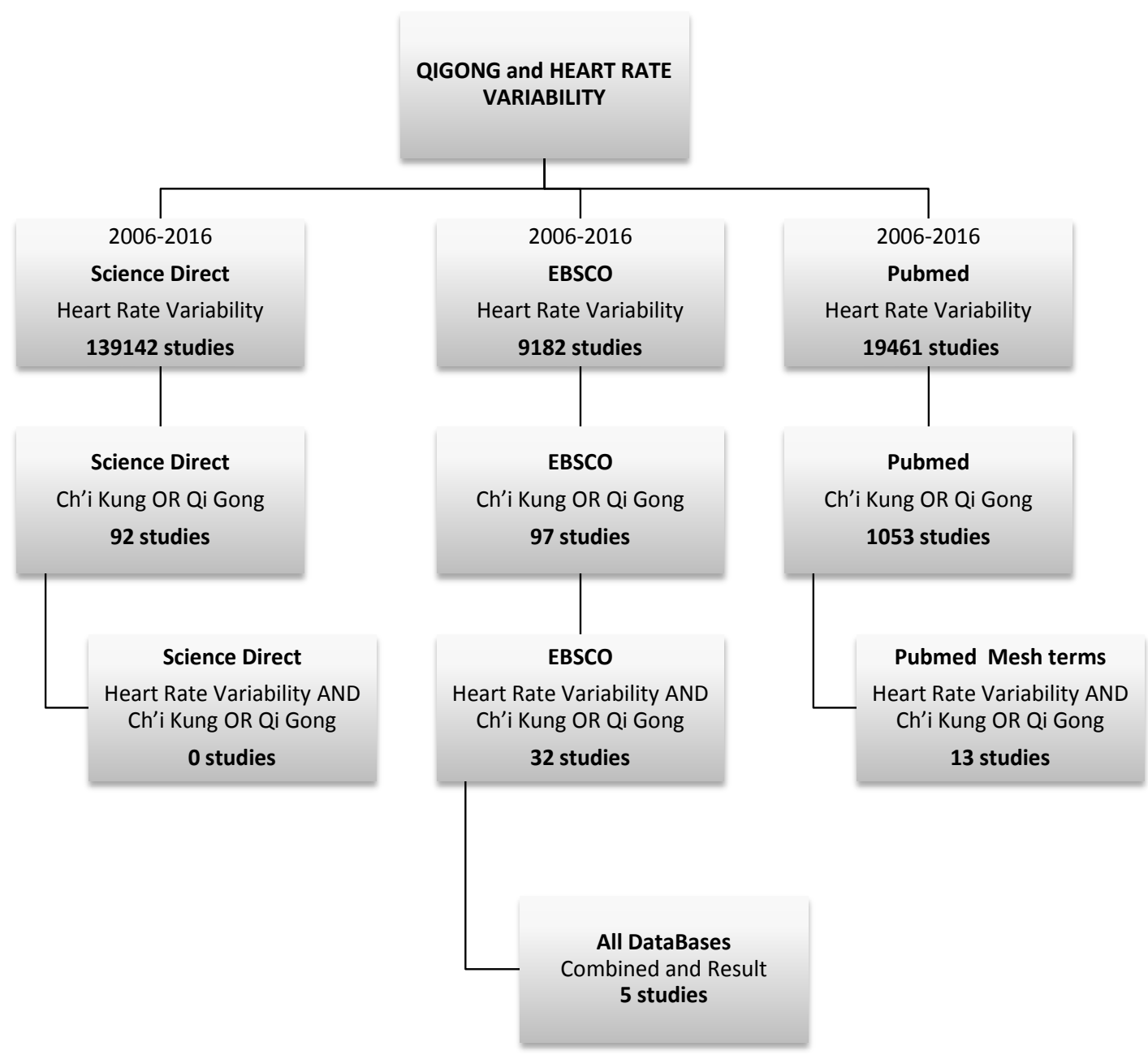

Figure 1. Article search and selection in all database. 
Table 1. Articles selected to compose the systematic review. $(\boldsymbol{\uparrow}=$ increase; $\boldsymbol{\Downarrow}=$ decrease $)$

\begin{tabular}{|c|c|c|c|c|c|}
\hline Author/year & Objective & Intervention & Method & Variables & Results \\
\hline $\begin{array}{l}\mathrm{Li}, \mathrm{R} . \text { et } \\
\text { al./2014 }\end{array}$ & $\begin{array}{l}\text { Effects of } 16 \\
\text { weeks of Qigong } \\
\text { Baduanjin to } \\
\text { fitness and health }\end{array}$ & $\begin{array}{l}\text { Ba DuanJin Qi } \\
\text { gong }\end{array}$ & $\begin{array}{c}\text { GC- } 55 \text { sedentary } \\
\text { subjects; GE- } 55 \text { trained } \\
\text { individuals-(learned } \\
\text { Qigong } 2 \text { weeks before the } \\
\text { start); } 34.2 \text { years } \\
16 \text { weeks of Qi gong Ba } \\
\text { DuanJin } \\
\text { 3x/week } 30 \text { to } 60 \text { minutes }\end{array}$ & $\begin{array}{c}\text { Total cholesterol } \\
\text { (TC); Serum } \\
\text { Triglycerides, LDL, } \\
\text { HDL, } \\
\text { SDS (depression } \\
\text { scale) } \\
\text { Body fat percentage; } \\
\text { Flexibility; BMI and } \\
\text { circumferences; } \\
\text { Blood pressure; } \\
\text { HRV, Vital capacity, } \\
\text { O2 consumption, } \\
\text { Max HR, Max } \\
\text { Ventilation; sit } \\
\text { and reach. }\end{array}$ & $\begin{array}{c}\text { Flexibility improvement } \\
\text { (improves coordination, } \\
\text { muscle Power, speed and } \\
\text { physical skills); improves } \\
\text { body mind coordination; } \\
\text { no significant difference } \\
\text { in the SDS (self rating } \\
\text { depression scale), } \\
\text { significant decrease } \\
\text { in the body fat } \\
\text { percentage; no significant } \\
\text { variation on blood } \\
\text { pressure, HRV, vital } \\
\text { capacity, max } \mathrm{O}_{2} \\
\text { consumption and } \\
\text { max ventilation. }\end{array}$ \\
\hline $\begin{array}{l}\text { Chang, } \\
\text { M-Y/2014 }\end{array}$ & $\begin{array}{l}\text { Effects of } 12 \\
\text { weeks of qi gong } \\
\text { (8 moves) on } \\
\text { HRV and } \\
\text { perypheral vaso- } \\
\text { motor } \\
\text { response. }\end{array}$ & $\begin{array}{c}8 \text { moves } \\
\text { Dharma } \\
\text { Drum's-Qi gong }\end{array}$ & $\begin{array}{c}\text { Pre and Post test } \\
77 \text { subjects } \\
\text { 47-EQG (experimental } \\
\text { qi gong) } \pm 62.98 \text { years } \\
30 \text { CG (control } \\
\text { group) } \pm 65.07 \\
\text { years } \\
12 \text { weeks } \\
30 \text { ' qi gong-3x week }\end{array}$ & $\begin{array}{l}\text { HRV-SDNN, low } \\
\text { frequency, high } \\
\text { frequency and total } \\
\text { Power. } \\
\text { PVR (peripheral } \\
\text { vasomotor response) }\end{array}$ & $\begin{array}{l}\uparrow \text { sdnn } \\
\uparrow \text { low frequency } \\
\uparrow \text { high frequency } \\
\uparrow \text { total power }\end{array}$ \\
\hline $\begin{array}{l}\text { Chang, C; Tsai, } \\
\text { G \& Hsieh, } \\
\text { C-J/2013 }\end{array}$ & $\begin{array}{l}\text { Laughing Qigong } \\
\text { effects on } \\
\text { psychological, } \\
\text { immunological } \\
\text { and physiological } \\
\text { systems and to } \\
\text { make LQP a } \\
\text { standard method } \\
\text { to simulate } \\
\text { laughing } \\
\text { interventions. }\end{array}$ & $\begin{array}{l}\text { Laughing Qi } \\
\text { Gong Program } \\
\text { (LQP) and Facial } \\
\text { Scale before and } \\
\text { after each } \\
\text { session of LQP }\end{array}$ & $\begin{array}{c}\text { Quantitative and } \\
\text { qualitative study } \\
\text { Control and experimental } \\
\text { groups (CG and EG), } \\
67 \text { teenagers }=34 \text { (EG) } \\
\text { (16 male and } 18 \text { female) } \\
\text { and } 33 \text { (CG) (18 male and } \\
15 \text { female) } \\
2 \text { months, } 8 \text { sessions of } 45 \\
\text { minutes (LQP) and } 15 \\
\text { min (data collection) CG } \\
\text { (reading or doing } \\
\text { homework for } 1 \text { hour) }\end{array}$ & $\begin{array}{l}\text { Rosemberg's scale for } \\
\text { self steem (RSE), } \\
\text { chinese humor scale } \\
\text { (CHS), subscales } \\
\text { from CHS (HC } \\
\text { humor creativity), } \\
\text { (HT humor trend), } \\
\text { facial scale (FS); } \\
\text { Blood pressure (BP), } \\
\text { Heart rate variability } \\
\text { (HRV); Salivar } \\
\text { cortisol analysis }\end{array}$ & $\begin{array}{c}\text { EG showed significant } \\
\text { improvement in CHS } \uparrow \text {, } \\
\text { specifically for HC } \uparrow \text {; } \\
\text { Humor state improved in } \\
\text { the FS; cortisol } \downarrow \text {, HRV } \\
\text { showed } \\
\text { significant difference } \\
\text { when compared to CG. }\end{array}$ \\
\hline $\begin{array}{c}\text { Goshvarpour, } \\
\text { A. e } \\
\text { Goshvarpour, } \\
\text { A./2012 }\end{array}$ & $\begin{array}{l}\text { To analyze and } \\
\text { compare the } \\
\text { contribution of } \\
\text { the quadratic } \\
\text { phase of HRV } \\
\text { during } 2 \text { different } \\
\text { meditation } \\
\text { models. }\end{array}$ & $\begin{array}{c}\text { Chinese Qi gong } \\
\text { and Kundalini } \\
\text { Yoga }\end{array}$ & $\begin{array}{c}\text { Qi gong Group ( } 5 \text { male } \\
\text { and } 3 \text { female } \pm 29 \text { years) } \\
\text { Kundalini Yoga Group ( } 2 \\
\text { male and } 2 \text { female } \pm 33 \\
\text { years) } \\
\text { Qi gong ( } 1 \text { - } 3 \text { months of } \\
\text { practice before data } \\
\text { collection)-1 hour of Qi } \\
\text { gong meditation. } \\
\text { Kundalini Yoga } \\
\text { (meditation advanced } \\
\text { training level)-1 hour of } \\
\text { Kundalini meditation }\end{array}$ & $\begin{array}{c}\text { Heart rate } \\
\text { signals-Holter } \\
\text { monitor- } \\
\text { HOS-higher order } \\
\text { spectra } \\
\text { QG-holter } 10 \text { hours } \\
\text { during DLA, } 5 \text { hours } \\
\text { of recording from the } \\
1 \text { hour practices. } \\
\text { KY-holter-1:30 hr } \\
\text { and } 15 \text { min of easy } \\
\text { breathing before } 1 \\
\text { hour of meditation. } \\
\text { For both the sample } \\
\text { rate was } 360 \mathrm{~Hz} .\end{array}$ & $\begin{array}{l}\text { Different forms of } \\
\text { meditation could change } \\
\text { specific components of } \\
\text { HRV signals and the can } \\
\text { have specific health } \\
\text { benefits. }\end{array}$ \\
\hline
\end{tabular}




\begin{tabular}{|c|c|c|c|c|c|}
\hline $\begin{array}{l}\text { Kuan, S-C, } \\
\text { et al./2012 }\end{array}$ & $\begin{array}{l}\text { To test the effects } \\
\text { of } 12 \text { weeks of a } \\
\text { Qigong exercise } \\
\text { program n } \\
\text { psychological and } \\
\text { physiological } \\
\text { health in } \\
\text { wheelchair } \\
\text { older adults. }\end{array}$ & $\begin{array}{l}\text { Qigong } \\
\text { Ho-gong }\end{array}$ & $\begin{array}{l}72 \text { older subjects, Wheel } \\
\text { chair users of similar } \\
\text { problems-65 years or } \\
\text { more with cognitive } \\
\text { integrity; CG-38 subjects } \\
\text { without qigong, yoga or } \\
\text { tai chi chuan for at least } 3 \\
\text { months); EG-34 subjects } \\
\text { for Qigong Ho-gong } \\
\text { classes. } \\
12 \text { weeks-Qi gong } \\
\text { Ho-gong practice } \\
\text { (adapted to Wheel chairs) } \\
5 x / \text { week- } 35 \text { minutes }\end{array}$ & $\begin{array}{c}\text { Blood pressure (BP), } \\
\text { Heart Rare } \\
\text { Variability (HRV); } \\
\text { distant skin } \\
\text { temperature (DST) } \\
\text { and Brief Symptom } \\
\text { Rating Scale } \\
\text { (BSRS-5) }\end{array}$ & $\begin{array}{l}\text { Systolic and diastolic } \\
\text { pressures, distant skin } \\
\text { temperature small } \\
\text { increase (DST), no } \\
\text { changes in the HRV, } \\
\text { significant improvement } \\
\text { in the psychological } \\
\text { health; }\end{array}$ \\
\hline
\end{tabular}

Laughing Qì Gōng Program (Smile Qì Gōng), Chinese Qì Gōng (there was no style specification, but it was reported that it was a practice of Qì Gōng in the sitting position) and the Ho-gong (a type created for wheelchair users and elderly people). This type is acombination of some methods such as yi-ging-xisueygong (column adjustment method), yang shu sheng (method to nourish vital energy), dao yin shu (method of guidance and leadership) and Tu-na (breathing control method), and this combination of methods was intended to frail people to be practiced in any place and time with the objective of strengthening the Vital Energy, as well as all the other methods, types and/or styles of Qì Gōng [6].

The practice time ranged from 4 to 16 weeks, although we found 3 studies with 12 weeks of practice [6] [8] [9] used 16 weeks of practice between 30 and 60 minutes. In [8] there was an acute data collection after 1 hour of meditation, but the required practice time (participant experience) of Qì Gōng to engage in the experiment was around 4 to 12 weeks.

The Qi Gong sessions had at least 30 minutes and a maximum of 60 minutes of duration, with two studies of 30 minutes [9] [10]. In [9] this time ranged from 30 to 60 minutes, meanwhile Chang, Tsai and Hsieh (2013) presented a variable time amount: 45 minutes to the group sessions and 60 minutes for the sessions done at home.

Weekly frequency ranged from $3 \times$ a week ( 2 studies) [7] [9]; 1 time [10], 5 times [6] and an acute collection [8].

The participants of the studies were heterogeneous regarding their ages. There were studies with teenagers (age not defined) [10]; adults (29 to 34.2 years) [8] [9]; elderly (62.98 or more) [6] in one study(with elderly people), the main feature was to be in a wheelchair.

When we analyze the HRV results, one study [9] (using a heart rate monitor, Polar RS 800CX, Polar Finland) with adults ( 234.2 years) found no significant difference. They analyzed the RR interval, the very low frequency (VLF), low frequency (LF), high frequency (HF) and Total Power.

In the study of Goshvarpour and Goshvarpour (2013) [8], used bispectrum magnitude analysis, estimated through three techniques, tendencious, parame- 
tric and direct (FFT). They found variations of different components of HRV in young adults ( 29 years) with a significant decrease in the magnitude of the heart rate bispectrum. This type of analysis generates extra data that gives more information than the traditional power spectrum analysis.

That study was reinforced by another research with a meditation technique called Vipassana. The author analyzed LF and HF from adults ( 43.8 years) after 10 days of an intensive course of the technique. Normalized HF data was significantly different and the authors believed that happened due to a decrease in LF values instead of an increase of HF itself [11].

According to these authors, normalized data represents an advantage because it presents the measurement of the vagal output, not presented by other spectral analysis. These oscilating data (LF increase, HF increase or HF increase due to LF decrease) happens because meditation techniques have a slow breathing pattern that influences HRV components, as described in another study published by Leher (1992) [4]. Therefore, a careful analysis is needed when pure data is compared to normalized data in situations where the respiratory frequency might change the results [11].

HF, LF and the low frequency/high frequency (LF/HF) ratio were analyzed in the teenager group doing the Smile Qi Gong. Although the authors didn't specify the tool used to analyze this variable, there was a significant difference in the control group, with different results when compared to some other studies from the literature. That probably happened because the control group was submitted to stress relief activities such as reading and writing. Besides, the experimental group suffered cross contamination, they did not comply with the rules of predetermined rest for the proper measurement of the variable, probably because of inadequate behavior related to their age.

The above results are in opposition with those obtained by [12] and [13], they found gains in the parasympathetic nervous system modulation reflecting in a better HRV in teenagers. In the first study Sharma et al. (2015) [12], the better HRV was associated to a larger estrogen concentration. This hormone, according to this study [12], increases the parasympathetic system modulation, when female teenagers are compared to their counterparts (male teenagers). In the second study [13] when teenageathletes from both genders were compared, the difference found was not related to the gender, but to a better parasympathetic modulation imposed by physical training. In another gender and ethnic differences study, HRV was improved in black teenagers, especially those who did moderate cardiovascular activities [13].

One of the studies analyzed HRV (BFM 5000 plus) with spectral analysis in the elderly, they analyzed SDNN, total power, HF, LF and the LF/HFratio. They found an increase of SDNN, total power, HF, LF and no significant difference in the LF/HF ratio. These results are in opposition to the findings of another study with Qì Gōng and HRV (presented below).

Elderly individuals that were wheelchair users were also submitted to an adapted form of Qì Gōng, so they could perform the movements. Their HRV 
was measured by a portable equipment manufactured by DailyCare. No significant differences were found for HRV [6].

Lopes et al., (2007) [14] found in their study that strength training can improve HRV, especially in young people, but that was not seen in the elderly, since variability declines with the physiological process of aging because of depletion of the vagal tonus, increase in the sympathetic activity and the presence of diseases such as hypertension or heart failure.

Jandackova et al. (2016) [15] corroborates the notion that aging impairs HRV. They show that individuals present a decrease in autonomic control with a considerable reduction of heart rate variability. Therefore, the absence of results with the Qi Gong intervention in HRV is expected since different studies used different strategies with varied magnitudes.

We believe that meditative activities such as Qì Gōng promote changes in the autonomic nervous system (ANS), depending on the level of concentration of the participant and that is improved when it is synchronized to a slow breathing rhythm.

However, because this practice has several types with different forms of Qi Gōng presented in the studies used in this review, HRV analysis can be performed with different equipment, and finally the age differences of the experimental groups in the studies, studies with similar methods are needed to assure the Qì Gōng positive effects in HRV pointed in this review.

\section{Conclusions}

We concluded that Qi Gong promotes improvement in some of the Heart rate variability parameters, but there is no evidence to further detail this improvement.

Therefore, we suggest that further studies regarding both, longer time of practice and equal time interval and instruments used to analyze HRV are necessary to confirm such benefits.

\section{References}

[1] Matos, L.C., Sousa, C.M., Gonçalves, M., Gabriel, J., Machado, J. and Greten, H.J. (2015) Qigong as a Traditional Vegetative Biofeedback Therapy: Long-Term Conditioning of Physiological Mind-Body Effects. BioMed Research International, 2015, Article ID: 531789.

[2] Freeman, S.R., Hanik, S.A.E., Littlejohn, M.L., et al. (2014) Sit, Breathe, Smile: Effects of Single and Weekly Seated Qigong on Blood Pressure and Quality of Life in Long-Term Care. Complementary Therapies in Clinical Practice, 20, 48-53.

[3] McCraty, R. and Shaffer, F. (2015) Heart Rate Variability: New Perspectives on Physiological Mechanisms, Assessment of Self-Regulatory Capacity, and Health Risk. Global Advances in Health and Medicine, 4, 45-61. https://doi.org/10.7453/gahmj.2014.073

[4] Leher, P. (1992) Applied Psychophysiology: Beyond the Boundaries of Biofeedback (Mending a Wall, a Brief History of Our Field, and Applications to Control of the Muscles and Cardiorespiratory Systems). Applied Psychophysiology and Biofeedback, 28, 291-304. 
http://www.ncbi.nlm.nih.gov/entrez/query.fcgi? cmd=Retrieve\&db=PubMed\&dopt= Citation\&list_uids $=14686082$ https://doi.org/10.1023/A:1027330909265

[5] Acharya, U., Joseph, K., Kannathal, N., Lim, C. and Suri, J. (2006) Heart Rate Variability: A Review. Medical \& Biological Engineering \& Computing, 44, 1031-1051. https://doi.org/10.1007/s11517-006-0119-0

[6] Kuan, S.-C., Chen, K.-M. and Wang, C. (2012) Effectiveness of Qigong in Promoting the Health of Wheelchair-Bound Older Adults in Long-Term Care Facilities. Biological Research for Nursing, 14, 139-146. https://doi.org/10.1177/1099800411399645

[7] Chang, M.-Y. (2015) Qigong Effects on Heart Rate Variability and Peripheral Vasomotor Responses. Western Journal of Nursing Research, 37, 1383-1403. https://doi.org/10.1177/0193945914535669

[8] Goshvarpour, A. and Goshvarpour, A. (2013) Comparison of Higher Order Spectra in Heart Rate Signals during Two Techniques of Meditation: Chi and Kundalini Meditation. Cognitive Neurodynamics, 7, 39-46. https://doi.org/10.1007/s11571-012-9215-Z

[9] Li, R., Jin, L., Hong, P., et al. (2014) The Effect of Baduanjin on Promoting the Physical Fitness and Health of Adults. Evidence-Based Complementary and Alternative Medicine, 2014, Article ID: 784059. https://doi.org/10.1155/2014/784059

[10] Chang, C., Tsai, G. and Hsieh, C.J. (2013) Psychological, Immunological and Physiological Effects of a Laughing Qigong Program (LQP) on Adolescents. Complementary Therapies in Medicine, 21, 660-668.

[11] Krygier, J.R., Heathers, J.A.J., Shahrestani, S., Abbott, M., Gross, J.J. and Kemp, A.H. (2013) Mindfulness Meditation, Well-Being, and Heart Rate Variability: A Preliminary Investigation into the Impact of Intensive Vipassana Meditation. International Journal of Psychophysiology, 89, 305-313.

[12] Sharma, V.K., Subramanian, S.K., Arunachalam, V. and Rajendran, R. (2015) Heart Rate Variability in Adolescents: Normative Data Stratified by Sex and Physical Activity. Journal of Clinical and Diagnostic Research, 9, CC8-CC13. https://doi.org/10.7860/jcdr/2015/15373.6662

[13] Gutin, B., Howe, C.A., Johnson, M.H., Humphries, M.C., Snieder, H.M. and Barbeau, P. (2005) Heart Rate Variability in Adolescents: Relations to Physical Activity, Fitness, and Adiposity. Medicine \& Science in Sports \& Exercise, 37, 1856-1863. https://doi.org/10.1249/01.mss.0000175867.98628.27

[14] Lopes, F., Pereira, F., Reboredo, M., et al. (2007) Redução Da Variabilidade Da Freqüência Cardíaca Em Indivíduos De Meia-Idade E O Efeito Do Treinamento De Força. Revista Brasileira de Fisioterapia, 11, 113-119. https://doi.org/10.1590/S1413-35552007000200005

[15] Jandackova, V.K., Scholes, S., Britton, A. and Steptoe, A. (1999) Are Changes in Heart Rate Variability in Middle-Aged and Older from a Large Population-Based Longitudinal Cohort Study. Journal of the American Heart Association, 5, e002365. 
Submit or recommend next manuscript to SCIRP and we will provide best service for you:

Accepting pre-submission inquiries through Email, Facebook, LinkedIn, Twitter, etc. A wide selection of journals (inclusive of 9 subjects, more than 200 journals)

Providing 24-hour high-quality service

User-friendly online submission system

Fair and swift peer-review system

Efficient typesetting and proofreading procedure

Display of the result of downloads and visits, as well as the number of cited articles Maximum dissemination of your research work

Submit your manuscript at: http://papersubmission.scirp.org/

Or contact jbm@scirp.org 